\title{
E-learning and blended learning
}

\author{
AL-Dulaimi Hassan Khlebus ${ }^{\mathrm{a}^{*}}$, AL-Ajeeli Ridha Tomma ${ }^{\mathrm{b}}$, AL-Tameemi Raed \\ Ramthan $^{\mathrm{c}}$ \\ ${ }^{a, b, c}$ University of Bucharest, Faculty of Psychology and Educational Sciences, Bucharest ,Romania, \\ ${ }^{a, b, c}$ Ministry of Education( Iraq) \\ ${ }^{a}$ Email: hassanredha33@yahoo.com \\ ${ }^{b}$ Email: alajeeliridha@gmail.com \\ ${ }^{c}$ Email: rrhrrh4@gmail.com
}

\begin{abstract}
The main objective of this paper is to identify the methods trough which e-learning has developed over the last years and also identify how the new technologies have blended into the teaching methods in today’s education system by blended learning. The fast development of technology has changed society in many aspects of our daily life and it is important to evaluate how these changes have impacted the education system. The paper is divided into the following five sections: an introduction in which the main hypothesis of the paper will be presented including a short review of the literature regarding the topic of e-learning. The introduction is followed by materials and methods, then the presentation of results followed by a discussion in base of the results. At the end the conclusions will be presented.
\end{abstract}

Keywords: E-learning; blended learning; education.

\section{Introduction}

The fast development of technology has changed society in many aspects of our daily life, it is only normal that many aspects have also changed in the student's life and their habits as well, therefore it should and does have an impact on education and this impact consists in the fact that technology should become part of the education program [8].

\footnotetext{
* Corresponding author.
} 
According to [5], integrating technology and educational technology in the curriculum would increase the engagement of students, would make it easier for them achieve the educational goals by creating a more active learning environment and would better fit their educational needs and skills. Educational technology does not imply the fact that students must use individual computers only, it can involve networking - videoconference, digital television- and other applications that allow students to interact with programs. It also includes digital cameras and electronic whiteboards [12;14].

In the past few years, decisions regarding what types of technology should be used and how to use technology in education have been questioned [8], but studies suggest that the types of technology that should be used and the ways to used that technology should be fit and appropriate for the students who use it and for the school's teaching methods and goals, adapting to the curricula in order to help achieving the expected results [11].

E-learning has two main approaches, it can be based on individual study or it can be facilitated by a teacher. Individual study is, of course completely independent so the strategies are fully chosen by the student, according to his or her preferences. According to Bates and Poole [4], e-learning emerged just at the appropriate timeframe when constructivist approaches to teaching were very popular and for constructivists, reflection and discussion are key activities through which knowledge is constructed and the nature of online teaching enables students to control to some extent the pace and timing of their learning, allows for and encourages reflection, while online forums provide the opportunity for students to test ideas, and build and construct knowledge through collaborative learning. E-learning courses facilitated by a teacher provide different levels of support from tutors and instructors, creating the highest collaboration and using a very interactive approach. Often, elearning courses combine both approaches. In terms of educational methods and policies, currently e-learning platforms have them under development. There are multiple definitions for e-learning. Greenberg [10] defines distance learning as a planned experience of teaching and learning using a variety of technologies to serve the students. It is designed to encourage student interaction, as well as certification [10]. In 1995, Desmond Keegan gave the most comprehensive definition: E-learning results from the technological separation between teacher and student, releasing the student from the need to travel in a certain place at a certain hour to meet a person who can train him/her [13].

The European Commission has characterized e-learning as the use of new technologies multimedia and the Internet to improve the quality of learning through access to resources and services as well as remote exchanges and collaboration.

In lesser words, the term e-learning is a generic expression for all learning involving the use of information and communication technologies (ICT) to support both learning and teaching. Its meaning here, therefore, is normally synonymous with ICT-based learning. The term may refer to the use of various technologies and tools to support learning in different contexts, including face-to-face settings and distance learning.

The „blended learning” term has begun to be used at the end of the 20th century and one of the older references appears in a press release in 1999 at Interactive Learning Centers and in 2006 the first manual of blended learning appears, written by C.J. Bonk and C.R. Graham who defined the blended learning systems as those 
systems which „combine the direct interaction between teachers and students with the teaching assisted by computer. Blended Learning is a modern teaching concept, very flexible, developed with the purpose of offering each student an advanced level of technical knowledge. The system is based on new concepts and teaching methods, being student-centered. It promotes both the study assisted by trainer and the individual online study. According to Garisson,[9] the blended learning concept is "a formal education program in which a student learns at least in part through online delivery of content and instruction with some element of student control over time, place, path or pace.” [9]. Blended learning is a combination of learning at a distance and the traditional classroom.

\section{Materials and methods}

The study contains a literature review which has been realized by selecting the most relevant articles written on the topic and it includes a personal interpretation of the results. Also there has been a comparative study of the available open source e-learning platforms. The used items were:

- It has an example of a lesson

- It is open source

- It has an available test for the evaluation of acquired knowledge or quizzes

- It has teacher-student interaction

- It has teacher-resources interaction

- It has student-resources interaction

- It has interactions between users

- It has asynchronous collaborative learning

- It has synchronous collaborative learning

- It allows export

- It allows import

- It has the function to create catalogs

- It allows lesson planning

- It is accessible via internet

- It contains documented and quality documentation in various languages

For each of the items, the value assigned was: present $=1$, partially present $=0.5$., absent $=0$. (See Table 2 in the results section).

\section{Results}

In blended learning, students have a fixed schedule where they will have to attend a part of the classes at the educational institution and for the rest, they can make their own schedule, attend the rest of the classes and do their coursework and assignments online. The table below illustrates the strategies, tools and resources for blended learning. 
Table 1: Strategies, tools and resources for blended learning and e-learning.

\begin{tabular}{|c|c|c|}
\hline Goal & Blended Learning & E-learning \\
\hline $\begin{array}{l}\text { - Communication between } \\
\text { teacher and students }\end{array}$ & $\begin{array}{ll}\bullet & \text { Full group lessons } \\
\text { - } & \text { Small group lessons or } \\
\text { tutorials } & \\
\text { - } & \text { Individual conferences } \\
\text { - } & \text { Marked assignments and } \\
\text { rubrics } & \\
\text { - } & \text { Digital course materials } \\
\text { - } & \text { Online discussions } \\
\text { - } & \text { E-mail } \\
\text { - } & \text { Instant messages } \\
\text { - } & \text { News announcements } \\
\text { - } & \text { Online calendar } \\
\text { - } & \text { Dropboxes } \\
\text { - } & \text { Online grade tool }\end{array}$ & $\begin{array}{ll}- & \text { Digital course materials } \\
\text { - } & \text { Online discussions } \\
\text { - } & \text { E-mail } \\
\text { - } & \text { Instant messages } \\
\text { - } & \text { News announcements } \\
\text { - } & \text { Online calendar } \\
\text { - } & \text { Dropboxes } \\
- & \text { Online grade tool } \\
- & \text { Rubrics } \\
- & \text { Web conferences }\end{array}$ \\
\hline $\begin{array}{lll} & \text { Collaboration } & \text { among } \\
\text { students }\end{array}$ & $\begin{array}{ll}\text { - } & \text { Learning centers or other } \\
\text { room arrangements } \\
\text { - } & \text { Class discussions } \\
\text { - } & \text { Face-to-face group work } \\
\text { - } & \text { Online group work } \\
\text { - } & \text { Online discussions } \\
\text { - } & \text { E-mail } \\
\text { - } & \text { Instant messages } \\
\text { - } & \text { Blogs } \\
- & \text { Electronic portfolios } \\
\text { - } & \end{array}$ & $\begin{array}{ll}\bullet & \text { Online group work } \\
- & \text { Online discussions } \\
- & \text { Chat sessions } \\
\bullet & \text { E-mail } \\
\text { - } & \text { Instant messages } \\
- & \text { Blogs } \\
- & \text { Electronic portfolios } \\
- & \text { Web conferences }\end{array}$ \\
\hline Demonstration of learning & 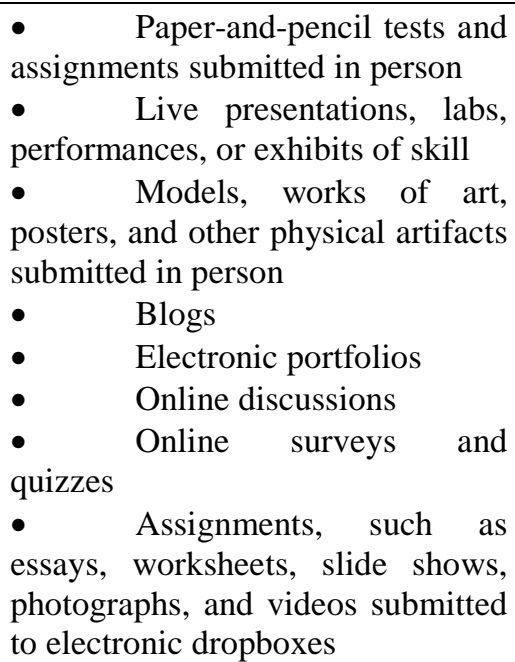 & $\begin{array}{ll}\text { - } & \text { Blogs } \\
\text { - } & \text { Electronic portfolios } \\
\text { - } & \text { Online discussions } \\
\text { - } & \text { Online surveys and } \\
\text { quizzes } & \\
\text { - } & \text { Assignments, such as } \\
\text { essays, worksheets, slide shows, } \\
\text { photographs, and videos submitted } \\
\text { to electronic dropboxes } \\
\text { - } \quad \text { Web conference }\end{array}$ \\
\hline
\end{tabular}

In order to transform a classic course in Blended Learning format, it is required for the content to be based on the specificity of each discipline and on the already existing digital materials. In order to create a Blended Learning course Web and Course Authoring instruments are usually used. An efficient Blended Learning course must be:

- $\quad$ Student centered

- $\quad$ Logically and attractively structured with graphs, tables, schemes, animations, simulations, hyperlinks 
- Interactive- it must contain multimedia and auto-evaluation means which can offer feedback regarding the progress of the students and the degree of understanding of the content.

Below there is a comparison study realized for the available open source e-learning platforms: Moodle, ATutor, Claroline, Hyper EDU, Logic Capmus, TYPO3, ILIAS and SAKAI.

Advanced eLearning - AEL is used in most schools in Romania. AEL is a complete integrated platform and it offers support for teaching and learning, testing and evaluation, having a curricular concept. In AEL, the content can be structured and adapted according to the student's needs.

The access rights for each user or group of users can be applied to each segment of the database of online library. The search is usually based on key words.

The e-learning platform Moodle offers communication and socializing environment, it has evaluation systems, courses and it give students the possibility of virtually working togethers. The main educational resource is represented by the e-course, which consists of lessons or weekly activities, assignments and homework. Ath the end of a course module, the evaluation module is activated.

The evaluation system is flexible and allows the trainer to establish more evaluation modialities. Teachers can post activities and students can post the assignments for feedback, grade or can make commentaries and debates. The Moodle infrastructure supports many types of plugins, such as:

- $\quad$ activities (game words, puzzles)

- $\quad$ resource types (multiple answers, trough or false)

- graphic themes

- $\quad$ authentication methods with usernames and passwords

- $\quad$ Content filters.

Atutor is a FREE Open Source LMS, used to develop online courses and create E-learning content. ATutor is used in various contexts, including online course management, continuing professional development for teachers, career development, and academic research.

The software is suitable for educational use according to software evaluation criteria established by The American Society for Training and Development (ASTD).

Claroline is a free software to manage online learnings, to create learning paths, MOOCs, plans of flipped classrooms and to facilitate collaborative learning. It was created in 2000 at the Catholic University of Louvain (UCL), and is the second most commonly used online learning application in Europe.

HyperEdu is an e-learning and blended learning enables students to schedule and complete online laboratory activities, having an infrastructure that implements an advanced resource pooling mechanism that dynamically allocates a number of virtual machines for each group of students that scheduled lab session. Implementation 
technologies:

- $\quad$ PHP - system management, web services, tool integration

- MySQL Server - database server

- $\quad$ XenServer - management of virtual machines

- $\quad$ Adobe Flash Platform

- $\quad$ HTML, JavaScript, JQuery, CSS

LogiCampus is a free and open source distance learning and course management platform for colleges, universities and schools. It's a free educational platform, providing a built-in master calendar, textbook requisitions and more. It has a simple, Intuitive user interface.

TYPO3 e-learning platform is cms-based platform, highly used in Germany, which appears to spread also in Europe, having an intuitive interface and offering high quality interactive software.

ILIAS is another german open source web-based learning management system (LMS). It supports learning content management (including SCORM 2004 compliance) and tools for collaboration, communication, evaluation and assessment.

The software is published under the GNU General Public License and can be run on any server that supports PHP and MySQL, which is why most consumers choose it.

The last open source chosen platform is SAKAI, which is not very popular, but it is simple to use and it has many features: Author collaboratively

- $\quad$ Store private content

- $\quad$ Share resources

- Develop presentations and blogs

- $\quad$ Private spaces for writing drafts and journals

- Group spaces for structured and unstructured collaboration

- Public spaces for blogs, wikis and portfolios

- $\quad$ Manage fully online courses

- Give community groups and organizations tools to be effective

- Synchronous and asynchronous interactions

According to the table it appears that the best open-source platforms, realizing most of the items, are ATutor, Moodle, HyperEdu, ILIAS and Claroline.

E-learning can be fully operational, or as I described earlier can function as an aid in the traditional education system. Bates and Poole [4] have described the functions of E-learning graphically as it is shown in the figure below. 
Table 2: Comparison between open source available platforms

\begin{tabular}{|c|c|c|c|c|c|c|c|c|}
\hline Activity & $\begin{array}{l}\text { Mo } \\
\text { odle }\end{array}$ & ATutor & Claroline & HyperEDU & LogicCapmus & TYPO3 & ILIAS & SAKAI \\
\hline $\begin{array}{l}\text { It has an example } \\
\text { of a lesson }\end{array}$ & 0 & 1 & 0 & 0 & 0 & 0 & 0 & 0 \\
\hline It is open source & 1 & 1 & 1 & 1 & 1 & 1 & 1 & 1 \\
\hline $\begin{array}{l}\text { It has an available } \\
\text { test for the } \\
\text { evaluation } \\
\text { acquired } \\
\text { knowledge } \\
\text { quizzes }\end{array}$ & 1 & 1 & 1 & 1 & 1 & 1 & 1 & 1 \\
\hline $\begin{array}{l}\text { It has teacher- } \\
\text { student interaction }\end{array}$ & 1 & 1 & 1 & 0.5 & 1 & 1 & 1 & 0.5 . \\
\hline $\begin{array}{l}\text { It has teacher- } \\
\text { resources } \\
\text { interaction }\end{array}$ & 1 & 1 & 1 & 0.5 . & 1 & 1 & 1 & 0.5 . \\
\hline $\begin{array}{l}\text { It has student- } \\
\text { resources } \\
\text { interaction }\end{array}$ & 1 & 1 & 1 & 0.5 . & 1 & 1 & 1 & 0.5 \\
\hline $\begin{array}{l}\text { It has interactions } \\
\text { between users }\end{array}$ & 1 & 1 & 1 & 0.5 . & 1 & 1 & 1 & 0.5 \\
\hline $\begin{array}{l}\text { It has asynchronous } \\
\text { collaborative } \\
\text { learning }\end{array}$ & 1 & 0 & 0 & 1 & 0 & 0.5 . & 0 & 0 \\
\hline $\begin{array}{l}\text { It has synchronous } \\
\text { collaborative } \\
\text { learning }\end{array}$ & 1 & 1 & 1 & 1 & 0 & 0.5 & 0 & 0 \\
\hline It allows export & 1 & 1 & 1 & 1 & 1 & 0 & 1 & 0 \\
\hline It allows import & 1 & 1 & 1 & 1 & 1 & 0 & 1 & 0 \\
\hline $\begin{array}{l}\text { It has the function } \\
\text { to create catalogs }\end{array}$ & 1 & 1 & 1 & 1 & 1 & 0 & 1 & 1 \\
\hline $\begin{array}{ll}\text { It } & \text { allows lesson } \\
\text { planning } & \\
\end{array}$ & 1 & 1 & 1 & 1 & 0 & 0 & 1 & 0 \\
\hline $\begin{array}{l}\text { It is accessible via } \\
\text { internet }\end{array}$ & 1 & 1 & 1 & 1 & 1 & 1 & 1 & 1 \\
\hline $\begin{array}{l}\text { It contains } \\
\text { documentation in } \\
\text { various languages }\end{array}$ & 0.5 . & 1 & 1 & 1 & 1 & 0.5 . & 0.5 . & 1 \\
\hline
\end{tabular}




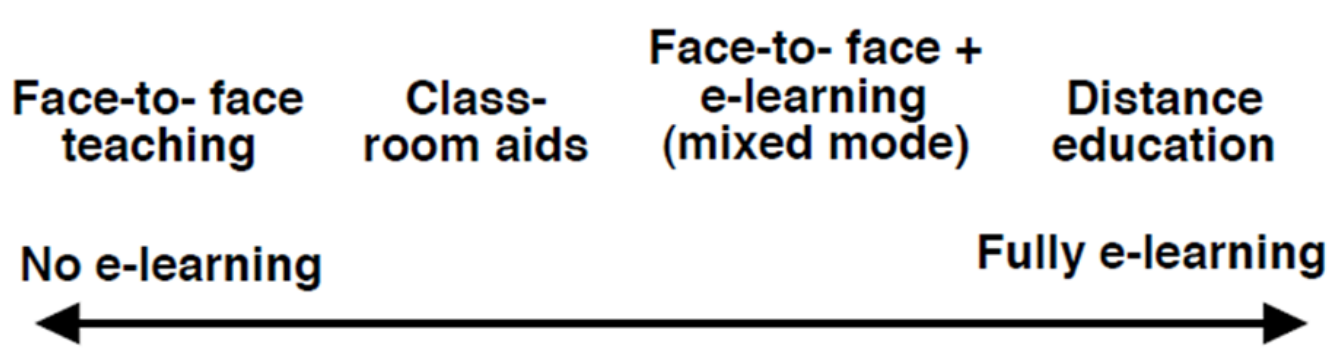

Figure 1: The continuum of e-learning [4]

E-learning has two main approaches, it can be based on individual study or it can be facilitated by a teacher. Individual study is, of course completely independent so the strategies are fully chosen by the student, according to his or her preferences.

E-learning courses facilitated by a teacher provide different levels of support from tutors and instructors, creating the highest collaboration and using a very interactive approach. Often, e-learning courses combine both approaches. In terms of educational methods and policies, currently e-learning platforms have them under development:

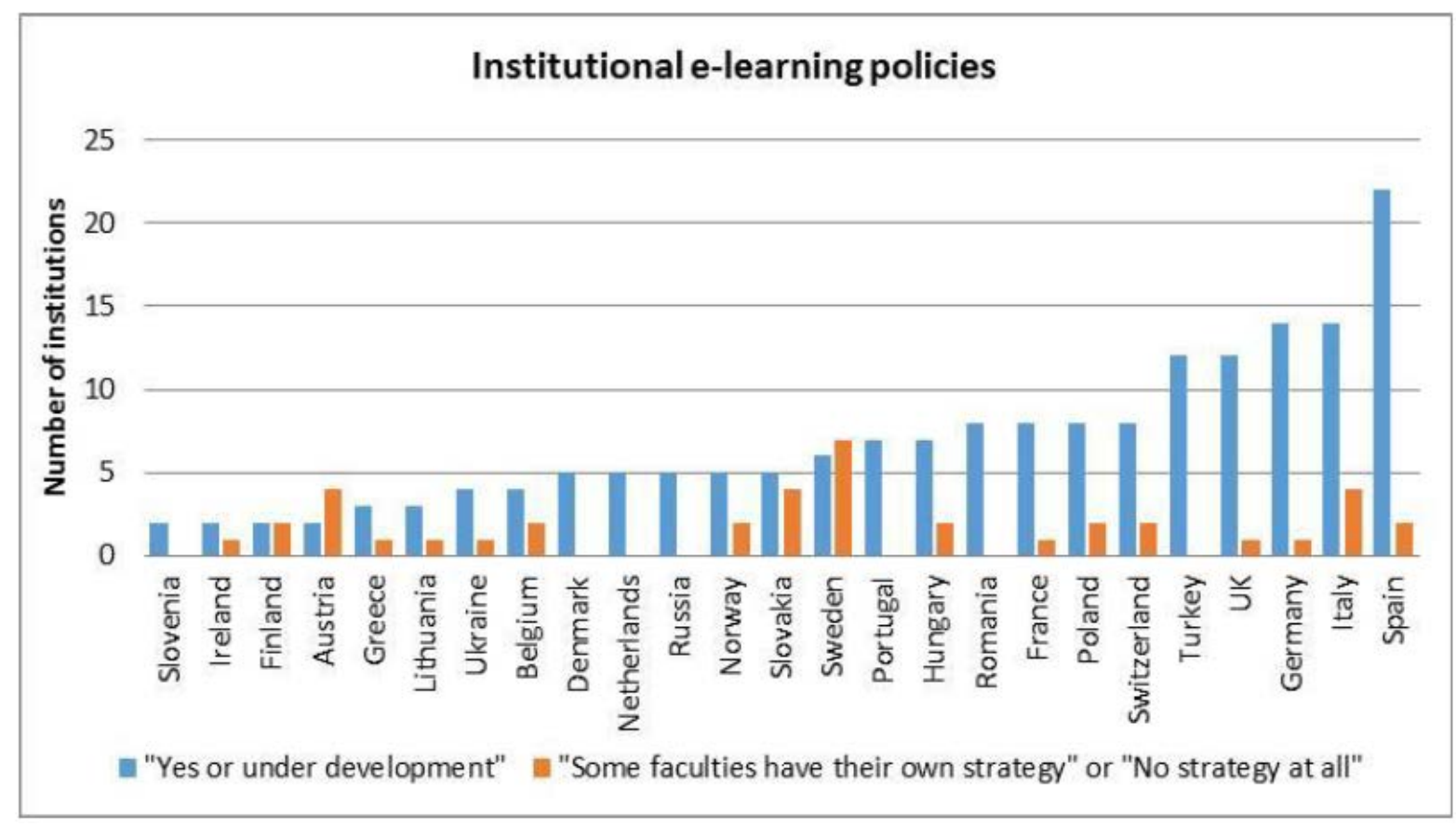

Figure 2: Development of e-learning policies [16]

This type of learning is suited for adults who have a hig-demanding job, or have a very busy life, since it allows a more flexible type of learning in terms of schedule. According to a recent survey in 2002 [1] over 1.6 million students in degree-granting higher education institutions in the USA took at least one online course in the fall 
semester of 2002 (11\% of all U.S. higher education students), and over 500,000 took all their courses online. Also, The Open University of Catalonia in Spain and Athabasca University in Canada, have over 20,000 students each, and most of the courses from these three institutions are fully online.

Even though the e-learning policies are under development, there are many instructional systems design models, most of which are based on popular ones such as the ADDIE model, which is show below.

\section{The ADDIE model for e-learning}

\begin{tabular}{|c|c|c|c|c|}
\hline ANALISYS & DESIGN & DEVELOPMENT & IMPLEMENTATION & EVALUATION \\
\hline \multirow{3}{*}{$\begin{array}{l}\text { NEEDS } \\
\text { ANALISYS } \\
\text { TARGET AUDIENCE } \\
\text { ANALISYS }\end{array}$} & LEARNING OBJECTIVES & \multirow{2}{*}{$\begin{array}{l}\text { CONTENT } \\
\text { DEVELOPMENT } \\
\end{array}$} & \multirow{2}{*}{$\begin{array}{l}\text { INSTALLATION } \\
\text { AND DISTRIBUTION }\end{array}$} & REACTIONS \\
\hline & SEQUENCING & & & LEARNINGS \\
\hline & INSTRUCTIONAL STRATEGY & $\begin{array}{l}\text { STORYBOARD } \\
\text { DEVELOPMENT }\end{array}$ & \multirow[t]{3}{*}{$\begin{array}{l}\text { MANAGING } \\
\text { LEARNER'S ACTIVITIES }\end{array}$} & BEHAVIOUR \\
\hline \multirow{2}{*}{$\begin{array}{l}\text { TASK AND TOPIC } \\
\text { ANALISYS }\end{array}$} & DELIVERY STRATEGY & \multirow{2}{*}{$\begin{array}{l}\text { COURSEWARE } \\
\text { DEVELOPMENT }\end{array}$} & & \multirow[t]{2}{*}{ RESULTS } \\
\hline & EVALUATION STRATEGY & & & \\
\hline
\end{tabular}

Figure 3: The Addie model for e-learning [17].

\section{Discussion}

In order to transform a classic course in Blended Learning format, it is required for the content to be based on the specificity of each discipline and on the already existing digital materials. In order to create a Blended Learning course Web and Course Authoring instruments are usually used.

An efficient Blended Learning course must be:

- $\quad$ Student centered

- $\quad$ Logically and attractively structured with graphs, tables, schemes, animations, simulations, hyperlinks

- $\quad$ Interactive- it must contain multimedia and auto-evaluation means which can offer feedback regarding the progress of the students and the degree of understanding of the content.

The Course Authoring instruments offer several tools for the creation of content of the courses (HTML, XML, PDF etc.) and allow the integration of multimedia files, such as images, audio and video files, animations, simulations, based on predefined templates and on the possibility of file conversion from various formats (Word, Power Point, Excell, PDF etc.).

The course must be organized in modules and chapters, contain tests and provide feedback with the purpose of visualizing the progress of the students in the learning process, in order to grade the student and generate the reports.

The Web Authoring Instruments offer the next important facilities for the creating and editing of the pages or 
websites trough predefined templates and styles, HTML pages management, creating page linkages, standardizing the layout of the pages, colors in order to ensure a unitary aspect of the entire website and offering dynamic and interactive pages for students.

Below, I will describe the steps required for the creation of an interactive course, according to Petrescu [15].

1. Identification of the objectives of the course

2. Identification of the number of activities required for achieving the objectives

3. Establishing of the required time for each activity

4. Creating the first course, by taking into account the following aspects:

a. Adding interactive resources to the content

i. Adding video resources

ii. Adding slide-shows

iii. Adding feedback resources

iv. Adding questionnaires

b. Adding traditional resources

c. Adding external resources

5. Creating weekly resources

a. Creating a stream of the lesson which would allow the teacher to control the interaction with the other available resources. Its purpose is to help with organization.

b. Adding a feedback form for each lesson.

6. Evaluation of the students:

a. By means of a multiple-choice test. Blended Learning Platform enables loading the questions and options for a multiple choice test and also real-time assessment. The teacher must only choose the questions and the rest of the process is automated.

b. By means of a dynamic test. The teacher can ask uploading the solutions for tasks on a platform.

c. By means of the classical test. The teacher can publish dynamic subjects and even receive resolutions, but the 
correction will be done manually.

d. The publication notes will be made through the catalog.

e. Clarification of the results is via a chat or a forum thread.

7. Consultations offered by teachers can be made through sessions or through private chat forums.

When properly implemented, blended learning can result in improved student success, satisfaction, and retention. Data analytics can also identify students who need early intervention, thus increasing retention and the available online tools can also significantly enhance student engagement, ensuring that all students participate in course discussions and benefit from collaborative learning.

Online learning platforms, or e-learning, is created to sustain the individual learning process and allow users and students to access a series of informational resources on online environments, allowing them to engage in a series of debates on various themes [16].

E-learning is not created in order to replace the traditional educational systems, but to act as an aid in the learning / teaching process. It has been adopted by the educational institutions as an alternative to the traditional educational strategies, being complementary to the school activity. This type of platform is designed for active learning, it involves the use of an internet connection and of a computer. For teachers it can be a useful teaching aid and it can help stimulate students to use their spare time more usefuly, creating activities specific to each subject or discipline.

E-learning has many benfits, and disdvantages as well. The first benefit is that it can engage a wider audience, since a virtual classroom is not limited to a number of students, the physical limitations being overcome [3].

An eLearning platform is an informatics system of management and content generation, composed from various components:

1. Learning Management System (Learning Management System) - LMS

2. Content Management System (Learning Content Management System) - LCMS

3. System of Human Resources Management and Knowledge (Human and Knowledge Management System) - HKMS

4. Synchronous platforms - Virtual Classroom

5. Portfolio management platforms - ePortfolio [2].

In the last decades, the electronic communication in the educational environment has become a constant of the last decades. The communication model has created an alternative learning support which marks a transfer of 
competences from an unidirectional, exclusivist learning model to a multidirectional model of educational communication, in the context of which the teachers has become the facilitator of the learning process for the students and the students has become more involved, no longer being just a passive observer.

After the 90s, when the Internet emerged, educational programs have been affected as well and the impact on the educational environment was to extend the local, physical access to education to the distance access, and this is was actually represented the e-learning 1.0, it was the first version.

The new technologies have put a greater emphasis on the needs and choices of the individual benefiting from the education, it has changed the entire educational system, the teaching methods, and the tools, offering greater opportunities for students and for teachers as well to develop professionally, to acquire new competences which have a great importance in our contemporary informational society.

The second version has developed due to the emergence of the e-Learning 2.0, which adopted the web 2.0 resources in the education environment, which is content generated by user, big scale of data, mass instruction, networking, social media, chat, Wikis, Blog, multimedia elements, sharing, and animations, as well as interactive content [2].

A new educational system in contemporary teaching is represented by e-learning, an educational system which has become more and more present in the universities and pre-university environments. The fundamental component of the e-learning systems is represent by specialized applications of teaching and evaluation. Online learning has a diverse spectrum of activities. There are many advantages that e-learning brings to the educational practice:

- Allows remote learning system, interactive;

- Generates and enables specific online assessments;

- Learning focuses on specific tasks according to the interest of the student or student's training allows a high degree of adaptability to the requirements of contemporary education systems;

- This type of education develops organizational skills and self-discipline learning time;

- Develops individualized learning practice, according to contemporary educational requirements;

Internet-based education and new media builds an educational model suitable to the needs of the young generation and offers an alternative to traditional education, especially for adults with busy schedules who have a full time job. Interest analysis developed in this study is directed at understanding the relationship existing between the traditional and the modern education.

Depth analysis of issues arising from new media used in education leads us to conclude that the online user has a more diversified leeway when accessing such systems. Compared to a traditional education system, new 
media has two fundamental characteristics. The first one is interactivity. The user accesses multiple online component, which gives various opportunities in this environment [6].

Secondly, it is the concept of ubiquity which in simplest terms is reduced to the idea of unlimited communication in the digital system. There is a relationship between the education system enforceability traditional and the contemporary type. The two systems complement each other to the benefit of general and specialized, offering a dynamic conclusive postmodern education and training systems.

Online learning platforms, or e-learning, is created to sustain the individual learning process and allow users and students to access a series of informational resources on online environments, allowing them to engage in a series of debates on various themes [16].

E-learning is not created in order to replace the traditional educational systems, but to act as an aid in the learning / teaching process. It has been adopted by the educational institutions as an alternative to the traditional educational strategies, being complementary to the school activity. This type of platform is designed for active learning, it involves the use of an internet connection and of a computer. For teachers it can be a useful teaching aid and it can help stimulate students to use their spare time more usefully, creating activities specific to each subject or discipline.

E-learning standards are developed by four main organizations: AICC, IEEE, IMS, and ADL thanks to the collaboration of 28 countries which are members of the ISO/IEC JTC1 SC36 committee (Bates, 2005). The standard has created a list of processes that influence the maintaining of quality of the e-learning systems:

- Vocabulary

- Collaborative technology

- $\quad$ Learner information

- $\quad$ Management and delivery of learning, education, and training

- Quality assurance and descriptive frame-works (ISO International Standardization Or-ganization )

The ISO/JTC1/SC36 committee is organized in five workgroups on the issues mentioned above.

The main activities which can be performed within an e-learning platform are:

- $\quad$ accessing e-courses - reading, taking notes, listening to audio resources or watching video resources

- $\quad$ deadline based assignments

- $\quad$ chat or forum for debates or discussions

- Web conference. 
Besides the open -source platforms described in table 2, there are also other relevant platform, described below, which are highly known in e-learning using universities.

Wikispaces is another well-known learning platform which is particularly interesting since users can load notes for classwork or creat interesting multimedia projects. Wikispaces can be used as simple websites, as project groups, in order to manage school documents, for debates or collaboration with other students or teachers, nationally and internationally. It was designed in order to be easy to use and fun, for teachers and students to be able to focus on what they want to achieve, so that the design is the most user-friendly in comparison to the other platforms.

ITeach is a 2.0 platform which allows teachers to collaborate in a highly advanced virtual environment.

Blackboard - offers the technical support required for the e-courses which are created according to the formative learning continutului based on a precise teaching strategy.

The projection of teaching in e-learning is called instructional design, and it is a systematic process, based on analysis and projection. It usually has four components: students, objectives, methods and evaluation and it consists in identifying the instruction needs in order to generate the e-learning strategy. The e-learning strategy is usually produced by a team consisting in experts on the taught discipline, in programming, copyright law, content writers etc. [7].

E-learning has many benefits, and disadvantages as well. The first benefit is that it can engage a wider audience, since a virtual classroom is not limited to a number of students, the physical limitations being overcome.

For distance education aimed at the masses, and in particular those excluded from traditional forms of education, e-learning education are likely to remain important for many years to come since the educational elearning platforms offer studying opportunities for those with a busy schedule, they act as a teaching aid, and they promote active learning and are very accessible.

One of the major advantages are that they stimulate interactivity and collaboration, the mobility and geographic independence, the fact that they can engage a higher audience and the individualization of the learning process which is a great benefit for the individual who can learn at his or her own pace and receive feedback.

In many countries, e-learning systems have proved that they can provide quality education and training to a large number of students at lower costs that traditional education and in the long term it is considered that elearning will be more cost-effective due to the fact that it can replace high labor costs with low-cost technology [4]. The first fully online public university in the world was the Open University of Catalonia (Universitad Oberta de Catalunya, UOC) which opened in 1996 and in 2003-2004 had 25000 students enrolled and enrollments are increasing by about $10 \%$ per year, while the enrolment in the traditional universities in Spain is declining. The courses of UOC are available in two languages, Catalan and Spanish and it offers 19 bachelor degreees, 9 master programs and a $\mathrm{PhD}$ on information society [4]. 
The funds are ensured directly by the regional Government of Catalonia and the university has developed its own technology infrastructure - the Virtual Campus - with the help of a staff who manages programs, a project team of teachers, multimedia designers, web designers and project managers. Another university which is developing its status as a well-known mainly online autonomous distance-learning university is Athabasca Universiy in Canada, which describes itself as the open university of Canada [4].

\section{Conclusions}

Nowadays, the organization of scholar teaching not only refers to contents, but also to methods and manners of delivering information. It matters more how we learn, than what we learn. Teaching must not lead to simple cumuls of information, but to a capacity of orientation, thinking and creativity. It must lead to a flexibility of cognitive structures and allow an optimal adaptation to the quick changes in our daily life.

Society nowadays relies very much on technology so it is expected that students and teachers have the required skills in order to successfully manage their tasks on a daily basis by using the tools technology delivers, tools meant to help us solve different problems in most of the levels of society.

So improving learning outcomes, preparing students to play an active role in society and maintaining a strong connection between the educational environment and society are some of the most important reasons why learning strategies are changing, and this shift appeared in the education system, promoting collaboration, interactive learning and the use of new technological teaching aids.

It appears that there is a trend in developing online learning platforms, so e-learning is expected to extend more in the years to come. The next generation of E-learning is not that far away in the future and is expected to be based on 3D interaction and cloud computing. It is important to understand that e-learning is not trying to replace traditional education systems, it is a complementary tool and an alternative to those individuals who do not have access to traditional teaching environments due to geographic issues, a busy schedule that do not allow them to attend fixed classes with no flexibility or very low flexibility, or even for people with disabilities for whom it would be difficult to attend classes in a traditional classroom. As technology is expanding and developing, our society shifts as well and is a good thing that education is adapting to these changes, since it leads to preparing actual students to be fully involved members of our current society and make meaningful contributions.

The contemporary education systems have suffered various modifications, by adapting to the requirements of the society with informational character. A large number of young people have enrolled in higher education, policies of human resources have developed based on efficiency and assimilation there have been various fluctuations in the work market and in this context the digital competences have pushed for the emergence of elearning. In many countries, e-learning systems have proved that they can provide quality education and training to a large number of students at lower costs that traditional education and in the long term it is considered that elearning will be more cost-effective due to the fact that it can replace high labor costs with low-cost technology.

For distance education aimed at the masses, and in particular those excluded from traditional forms of 
education, e-learning education are likely to remain important for many years to come since the educational elearning platforms offer studying opportunities for those with a busy schedule, they act as a teaching aid, and they promote active learning and are very accessible. One of the major advantages are that they stimulate interactivity and collaboration, the mobility and geographic independence, the fact that they can engage a higher audience and the individualization of the learning process which is a great benefit for the individual who can learn at his or her own pace and receive feedback.

It is important to understand that e-learning is not trying to replace traditional education systems, it is a complementary tool and an alternative to those individuals who do not have access to traditional teaching environments. To conclude, the role of educational technology in the development of education appears to be very important and educational technology should not only be perceived as a complementary tool, but become an integrative component since educational technology has numerous benefits for the students and teachers as well, when used accordingly to the standards and regulations.

\section{References}

[1] Allen, I. E. and Seaman, J. Sizing the Opportunity: The Quality and Extent of Online Education in the United States. Needham, MA: Sloan Center for Online Education, 2003.

[2] Anderson, P., "What is Web 2.0? Ideas, technologies and implications for education” in JISC reports, 2007

[3] Angrist, J., and Lavy, V. "New Evidence on Classroom Computers and Pupil Learning”, in The Economic Journal, 112 (October), 2002, pp.735-765.

[4] Bates, A.W. and Poole, G. Effective Teaching with Technology in Higher Education: Foundations for Success, San Francisco: Jossey-Bass, 2003.

[5] Bonifaz, A., \& Zucker, A. Lessons Learned About Providing Laptops for All Students. Newton, MA: Education Development Center. Retrieved October, 15, 2004.

[6] Britain, S., Liber, O., A Framework for Pedagogical Evaluation of Virtual Learning Environments, 2004.

[7] Bullen, M. Making the Transition to E-Learning: Strategies and Issues: Strategies and issues. Information Science Publishing, 2007.

[8] Culp, K.M., Honey, M., Mandinach, E. A Retrospective on Twenty Years of Education Technology Policy, Office of Educational Technology, U.S. Department of Education, 2003.

[9] Garisson, D. R., and Kanuka, H. "Blended learning: Uncovering its transformative potential in higher education.” In The Internet and Higher Education, 7, 2004, pp. 95-105. 
[10] Greenberg, G. “Distance education technologies: Best practices for K-12 settings”, in Technology and Society Magazine, 1998, 17 (4), pp. 36-40.

[11] Johnson, K.A. Do Computers in the Classroom Boost Academic Achievement? The Heritage Foundation, 2000.

[12] Jackson, L. Speaking of Electronic Whiteboards, Education World, 2008. Available online at: http://www.education-world.com/a/tech/tech/tech206.shtml [accessed Jun.13, 2017]

[13] Keegan, D. “Distance education technology for the new millennium: compressed video teaching”. In ZIFF Papiere. Hagen, Germany: Institute for Research into Distance Education. (Eric Document Reproduction Service No. ED 389 931). 1995.

[14] Marshall, J. "Implementation and Web-Based Learning: The Unimplemented Program Yields Few Results”, Computers in Schools, no. 21(3-4), 2004, pp.119-129.

[15] Petrescu, I. Ghid pentru elaborarea tesurselor de studiu in tehnologia educației la distanţă. 2011.

[16] Rosenberg, M. E-Learning: Strategies for Delivering Knowledge in the Digital Age. McGraw-Hill, 2001

[17] http://www.tonybates.ca/ - online learning resources. Accessed: May. 25, 2017 [June. 12, 2017]. 